\title{
SPINOZA THE HINDU: Advaita Interpretations of The Ethics
}

NOAH FORSLUND

$\mathrm{D}$ utch philosopher Baruch Spinoza holds a distinctive, if enigmatic, place in the Western philosophical canon. Although usually considered as a Cartesian rationalist, Spinoza's metaphysical and epistemological views continue to be considered somewhat anomalous within the Occidental tradition. ${ }^{1}$ Arguably, in fact, much of his influential Ethics espouses a substantively non-"Western" philosophical doctrine beneath orthodox rationalist terminology and organization. I contend that, although it employs decidedly Western-rationalist methods of inquiry, The Ethics actually proposes a system strikingly similar to the ontological-philosophical worldview found in Advaita Vedanta Hinduism. Core similarities between the schools include their (1) non-dualist, monistic metaphysical systems, (2) a strong relationship between humans and the divine, and (3) a potential for living liberation. This paper will consist of comparative analyses of metaphysical and epistemological facets of both the Advaita and Spinozistic philosophical traditions, including overviews of both schools, and concluding with a suggestion that these similarities might prompt a reexamination and critique of the oft-cited East-West dichotomy.

It may first be relevant to define briefly the binary system alluded to previously. The East-West dichotomy comprises a doctrine that divides socio-cultural, religious,

1 Russell, Bertrand. A History of Western Philosophy. (London: Allen \& Unwin, 1946), 458-461. 
and philosophical, traditions into two distinct camps, which are understood to inhabit fundamentally different realms. Customarily specified hallmarks of Western philosophy include a propensity towards rational intellectualization, the promotion of individualism, a rejection of mysticism, and often metaphysically, some conception of a personal God. Common stereotypes of Eastern philosophies include a skepticism toward pure rationalism and the intellect, mystical doctrines, and non-personal deities. Spinoza has perennially been placed firmly within the former canon $^{2}$; an examination of the substance of his works, however, might complicate this placement.

Although some antecedent scholarship has compared Spinozism to Eastern philosophical traditions, most analyses have been restricted to broad comparative surveys of Buddhism and Spinozism. In the past, researchers have provided several examinations that attempt to link the two philosophical schools. S.M. Melamed associates Spinoza's advocacy of a seemingly impersonal, or even non-existent, God to the Buddhist metaphysical picture of an "empty" universe. ${ }^{3}$ Both B. Ziporyn and Soraj Hongladarom cite Spinoza's union of mind and corporeal body as correlative to the Buddhist doctrine of non-self. ${ }^{45}$ Although some limited scholarship exists in this particular area of comparative analysis, few publications-if any-have considered comparisons between Spinozism and Advaita Vedanta Hinduism. The lack of literature regarding this similarity is surprising. In the next few paragraphs, I will broadly outline the two traditions individually, in order to procure, eventually, an examination of their similarities and differences.

We will begin with an overview of Advaita Vedanta philosophy. First espoused by Sankara in the 9th century CE, the tradition is rooted in interpretations of the Brahma Sutra, the Bhagavad Gita, and the Upanishads, three core Hindu religiophilosophical texts. Advaita is characterized by the fundamental belief that ultimate reality is solely brahman: that existence cannot be reduced to various distinct entities (like an individual soul, or an external world). Advaita Vedanta thus promotes a non-dualist, monist ${ }^{6}$ model of reality, in which all the world is a manifestation of the singularity of brahman (the word advaita literally means "non-dual" ${ }^{7}$ ). Additionally, brahman is infinite, and transcends the existence of the world. Although the world is

2 Russell, Western Philosophy, 459.

3 Melamed, S.M. Spinoza and Buddha: Visions of a Dead God. (Chicago: University of Chicago Press, 1933), 153-275.

4 Ziporyn, B. (2012). Spinoza and the Self-Overcoming of Solipsism. Comparative and Continental Philosophy, 4(1), 125.

5 Hongladarom, Soraj. "Spinoza \& Buddhism on the Self." The Oxford Philosopher, July 29, 2015.

6 It must be acknowledged, however, that the characterization of Advaita as a strictly "monist" philosophy has been cited as problematic by many adherents, scholars, and philosophers; Anantanand Rambachan writes, "Numerical categories, such as the number one, gain meaning from the existence of other numbers. When reality is nondual, we are constrained to use such categories with caution." (Rambachan, Advaita Worldview, 67) Haphazardly ascribing a numerical category to brahman might be seen as an attempt to limit the illimitable. Although we must be careful with complications that arise from such terminology, semantics aside, the ontological picture proposed in Advaita remains a non-dual, unified reality in brahman.

7 Brannigan, Michael C. The Pulse OfWisdom: The Philosophies of India, China, and Japan. (Stamford: Wadsworth/ Thomson Learning, 2000), 61. 
"non-different (ananya) from brahman [...] brahman is not identical with the world." ${ }^{8}$ In other words, although the world derives its existence and reality from brabman, the inverse is not true, because "the reality of brahman is independent and original." 9

Advaita scholars and philosophers consistently assert that brahman's limitlessness (ananta) renders any attempt at descriptive language ineffective. For this reason, brahman's true being is portrayed in Advaita as nirguna, or without characteristics. This contrasts with a portrayal of brahman as saguna, which signifies that explicit attributes are assigned. The concept of nirguna brahman requires that ultimate reality only be described negatively, as neti, neti ("Not this, not this"). ${ }^{10}$ Because brahman is infinite, linguistically assigning any qualities to it would only serve to limit its nature. Thus, brahman must remain ineffable.

Because all the world is essentially non-different from brahman, humans too are only manifestations of the divine. The cardinal assertion in the Advaita tradition is tat tvam asi: that the human self (atman) is non-different from brahman. This is further exemplative of non-dualism in Advaita. Individual selfhood is illusory, based upon a flawed understanding of ultimate reality. As long as the world (including the self) is perceived ordinarily (as distinct from brahman), a human remains in a state of ignorance (avidya). Avidya obstructs us from the highest quest for humanity: knowledge of our true selves and reality as identical to brahman. ${ }^{11}$

Ultimate liberation, called moksha, is achieved when a person realizes that atman is non-different from brahman. One prominent Advaita scholar neatly summarizes the concept of liberation, writing that "the unliberated person attributes a separate reality to the world, while the liberated sees the world as owing its existence and being to brahman." ${ }^{12}$ Moksha affords humanity the valid means of knowledge of ultimate reality, superior to human perception or reason (Sankara rejects these alternate sources of knowledge, because they rely on an observed object's finity). Nirguna brahman is without attributes ("form, sound, taste, scent, and sensation"), so the senses cannot hope to provide any understanding of ultimate reality. Similarly, although Sankara does not discount the importance of human reason (guided by the holy texts, such as the Upanishads), he does assert that brahman surpasses any human rational capacities: "although reasoning may be noticed to have finality in some, still in the present context it cannot possibly get immunity from the charge of being inconclusive." 13 Because brahman is both the means of knowledge and knowledge itself (insofar as brahman is ultimate reality), brahman must be known intuitively: "intuitive knowing is immediate as distinct from the discursive and mediate knowledge [...] It is the

8 Rambachan, Anantanand. The Advaita Worldview: God, World, and Humanity. (Albany, NY: State University of New York Press, 2006), 75.

9 Rambachan, Advaita Worldview, 77.

10 Brannigan, Pulse of Wisdom, 63.

11 Brannigan, Pulse of Wisdom, 64-65.

12 Rambachan, Advaita Worldview, 113.

13 Rambachan, Advaita Worldview, 49. 
perfect knowledge, while all other knowledge is indirect and imperfect insofar as it does not bring about an identification between subject and object." ${ }^{14}$ When a person has achieved moksha, he is liberated from ignorance through knowledge of all reality as brahman, which results in freedom from "sorrow, hate, grief, greed, and fear [... and] the attainment of peace and abiding happiness." 15

This, very broadly, summarizes the main tenets of the Advaita Vedanta tradition. Allow us now to compare this summary to the normative Eastern philosophical model outlined earlier in this paper. To recapitulate, oft-proposed hallmarks of Eastern philosophy include: (1) skepticism toward pure rationalism and the intellect, (2) the promotion of mysticism and the possibility of unity with the divine, and (3) a metaphysically non-personal God. Although the nuances of Advaita philosophy present some variance in practice and belief, we can generally understand the school to include these characteristics. Firstly, we have seen Sankara's rejection of human sensory experience and pure reason as sources of valid knowledge: that is, true knowledge of brahman can only be attained through intuitive understanding, guided by Hindu holy texts. Secondly, human union with brahman through the realization of tat tvam asi is the ultimate goal in Advaita philosophy. Thus, Advaita does promote a sort of mysticism, in which the self may be unified with, and liberated through, the divine. Thirdly, brahman is decidedly non-personal. The actions of brahman are unconcerned with human interests or desires. Instead, the world merely behaves according to brahman's essential nature-its grounding of reality. As Sankara writes, "God [brahman] can have activities of the nature of mere pastime out of His spontaneity without any extraneous motive [.... Any motive imputed to God can have neither the support of reason nor of the Vedas." ${ }^{16}$ Effectually, we see that the Advaita Vedanta school includes these three normative "hallmarks" of Eastern philosophy.

Now that we have summarized the Advaita philosophical tradition, we will continue with an overview of the Spinozistic philosophical system found in The Ethics. A foundational element of Spinoza's method lies in his argument that God must be the only substance that exists. The core of this Spinozistic concept lies in propositions that stem from Spinoza's definition of substance, which he defines as "that which is in itself and is conceived through itself; that is, that the conception of which does not require the conception of another thing from which it has to be formed." ${ }^{17}$ A substance is a thing that enjoys autonomous, self-contained existence, the understanding of which is not dependent upon the conception or existence of auxiliary things. Although an individual substance can have various affectations or modes within its being, these affectations are necessarily subsidiary to the substance

14 S. Radhakrishnan, trans., The Principal Upanishads. (London: Allen \& Unwin, Ltd., 1953), 96.

15 Rambachan, Advaita Worldview, 55.

16 Rambachan, Advaita Worldview, 91.

17 Spinoza, Baruch. The Ethics, Treatise on The Emendation of the Intellect, and Selected Letters. Translated by Samuel Shirley. Edited by Seymour Feldman. 2nd ed. (Cambridge: Hackett Pub. Co., 1992), 31. 
itself. As Spinoza writes, "substance is by nature prior to its affectations." ${ }^{18}$ Finally, extrapolating on the logic of these propositions, Spinoza argues that a substance, by nature, must be infinite (or hold infinite attributes), because the substance must exist independent of the existence of other bodies. Nothing can ever constrain a substance (and substances can never constrain each other).

It is from this foundational understanding of substance that Spinoza derives the claim that "there can be, or be conceived, no other substance but God," and, that, consequently, "whatever is, is in God, and nothing can be or be conceived without God." ${ }^{19}$ Because God is a perfect entity, he ${ }^{20}$ is the only thing that must necessarily exist by definition. Therefore, all other things exist subordinately to the existence of God, because he is constrained by nothing. God is the only thing that can be independently self-contained and self-caused, and, thus, fulfills the two defining characteristics of a substance. ${ }^{21}$ So, all of existence is God. Things we perceive to be individual entities actually comprise only finite modes within the substance of God, which is internally infinitely diverse and complex. It is here that Spinoza begins to use the terminology "God", or, "Nature", because God, as all of existence, is equated with the universe and Nature itself. Thus, Spinoza is generally understood to espouse a pantheistic, or a panentheistic-monistic philosophy, in which all existent things are unified in the oneness of God's eternal, infinite being. ${ }^{22}$

Due to God's perfection, morality in Spinozism is limited to the non-metaphysical, and God is decidedly non-personal. If the universe and God are one and the same, we cannot explain occurrences within Nature through human definitions of "good" or "bad." Ultimately, if God is the only substance, and therefore is the only causal power in existence, then all things in him "proceed from an eternal necessity and with supreme perfection." ${ }^{23}$ If all things are divine, then all events are perfect and necessary, insofar as they emanate directly from God. Thus, Spinoza presents us with an amoral universe, void of any differentiation between metaphysical "good" or "bad." This ontological schema advances a conception of a non-personal God, unconcerned with human activity or interests. As Spinoza writes, "Nature has no fixed goal (and) all final causes are but figments of the human imagination [...] God has acted in all things for the sake of himself, and not for the sake of the things to be created." 24

But where do humans fall in this metaphysical picture? If we are understood to be only finite modes of a non-personal divine entity, what becomes of our relationship

18 Spinoza, Ethics, 32.

19 Spinoza, Ethics, 39-40.

20 The masculine pronoun is only used here to conform to Spinoza's own word choice.

21 Hartshorne, Charles and William L. Reese. Philosophers Speak of God. (Amherst, NY: Humanity Books, 2000), 194.

22 Hartshorne, Philosophers Speak of God, 189-192.

23 Spinoza, Ethics, 59.

24 Spinoza, Ethics, 59. 
to the God? It is clear that the human self must be conceived as a part of God. Spinoza writes that the self ("man") consists of the unification of human mind and body, arguing that the mind is the self comprehended under the attribute of Thought, while the body is the self comprehended under the attribute of Extension. Because God is all things, God must therefore have the attributes of Thought and Extension. The human mind and body are both expressions of God under these different attributes. ${ }^{25}$ Yet, both objects, unified in the self, remain finite, individual parts of the singular substance that exists beyond them: "we are a part of Nature which cannot be conceived of independently of other parts." 26

It is here that Spinoza begins his discussion of the three types of human knowledge. The first type is derived from sensory experience, which only offers falsities, due to the subjectivity of the senses. The second is derived from common understandings of the world and its properties, unencumbered by subjectivity: that is, reason. The third and final kind of knowledge, Spinoza calls "intuitive," of which he writes, "proceeds from an adequate idea of the formal essence of certain attributes of God to an adequate knowledge of the essence of things." ${ }^{27}$ That is, essentially, intuitive knowledge is derived from an understanding that God is all of existence, and, thus, that the essences of all things are defined by his being. When a person has an adequate conception of God through an understanding of the true nature of reality (that is, Spinoza's pantheistic monism), he simultaneously has a true understanding of all things in existence, because they are one and the same. Therefore, intuitive knowledge is "necessarily true", emanating directly from the necessity of God's being. ${ }^{28}$

Spinoza believes that humans can ultimately achieve freedom through this intuitive knowledge. Through this adequate understanding of God, we may be liberated from the bondage of uncontrollable emotions (or "agitations of the mind") produced in us by "thoughts of external [non-divine] causes." ${ }^{29}$ Essentially, Spinoza argues, when we understand the ontological necessity of all things resulting directly from God's being, we can rationalize our way out of undesirable emotional responses. If the actions of an external body produce in us a sensation of fear-or anger, or sadnessintuitive knowledge allows us to realize the divine necessity of those actions, and to rationalize the emotion, negating it through thoughtful reflection. ${ }^{30}$ We move from being passive participants in our emotional state to being active participants in that state, through this intellectual process, as we simultaneously achieve salvation from ignorance. Therefore, as Spinoza writes, the highest blessedness that a human can achieve is found in this intuitive knowledge, which leads to an "intellectual love of

25 Spinoza, Ethics, 64-72.

26 Spinoza, Ethics, 156.

27 Spinoza, Ethics, 90.

28 Spinoza, Ethics, 91.

29 Spinoza, Ethics, 204

30 Spinoza, Ethics, 205-206. 
God", and, consequently, of all existence. ${ }^{31}$ Spinoza summarizes his liberative system, writing that "the wise man...suffers scarcely any disturbance of spirit, but being conscious, by virtue of a certain eternal necessity, of himself, of God and all things... always possesses true spiritual contentment." 32

Allow us first to compare the Spinozistic system to the normative Western philosophical model elucidated earlier. The Ethics certainly utilizes a Western rationalist lexicon and basic conceptual framework. Spinozistic terms like substance and attributes had been employed by precursory Western philosophers like Descartes and Malebranche, even if their definitions were slightly different. Similarly, the geometrical-method proofs found in the Ethics were certainly evident of a penchant for ordered intellectual inquiry. Thus, Spinoza clearly fulfills that first indication of the Western philosophical canon: he proposes his system in Western terms, employing a decidedly Occidental model.

Yet, Spinoza fails such a litmus test on all other indications. Firstly, with his promotion of pantheistic monism, Spinoza rejects individualism. Because God encompasses all of existence, and because a particular human solely comprises a modal manifestation of the divine, the supposed "individual" must in fact be unified with all other beings in the ultimate ontological picture. In his comparison of Spinozistic and Buddhist philosophy, Soraj Hongladarom neatly summarizes this retreat from individualism, writing that "the task of the human being is to achieve what [Spinoza] calls 'the intellectual love of God' [....] Here the uniqueness of this situation does not play a role; instead the idea is to forgo these traits of individuality by merging with the One, so to speak, through losing one's unique individual traits." ${ }^{33}$ Secondly, Spinoza espouses a version of philosophical mysticism wholly distinct from the Western canon. In The Ethics, human endeavors toward an intellectual love of God end with liberation through a realization of ultimate ontological union with God. This, in effect, sounds somewhat like Eastern mysticism, and further isolates Spinoza from traditional Western philosophy. Third, as explained earlier, Spinoza's God is decidedly non-personal, unconcerned with human interests; any attribution, of a human-serving "fixed goal," to Nature can only be "but a figment of the human imagination." 34

While The Ethics finds Spinoza rejecting many of the hallmarks of Western canonical models, the text strikingly parallels Advaita philosophy. What will follow will be an analysis of these likenesses.

Firstly, both Spinozism and Advaita Vedanta Hinduism present non-dualist, essentially monistic metaphysical systems. In Spinozism, God is the only independent substance

31 Spinoza, Ethics, 217-221.

32 Spinoza, Ethics, 223.

33 Hongladarom, "Spinoza \& Buddhism", no page numbers.

34 Spinoza, Ethics, 59. 
in existence-God alone is infinite, immutable, and eternal. All individual things comprise finite modes of God's substance, and are identical to God (insofar as they are themselves divine). Yet, God, with infinite attributes, transcends all possibilities of human perception; we only have access to God through the attributes of extension and thought, though God contains infinitely more attributes. Thus, God is infinitely greater than the observable universe, because God is constrained by nothing, including human faculties. This is strikingly similar to the unified ultimate reality proposed by Advaita Vedanta. Brahman alone comprises all existence as an infinite, eternal being. The world and individual humans are finite expressions of brahman's nature, and are non-different from brahman. However, the infinite nature of brahman indicates that ultimate reality is not encompassed by the world alone, as brahman can neither be constrained nor defined by any external body. Both Spinozism and Advaita propose monistic, transcendent divine beings, which encompass all of reality and existence, and which exist independently of any subordinate entity.

A further metaphysical parallel between Spinoza's God and Advaita's brahman is that both provide the ontological grounding for ultimate reality, but both are nonpersonal. We have seen how Spinoza's God is unconcerned with human interest and desire, merely acting "in all things for the sake of himself," ${ }^{35}$ according to the necessity of God's nature. Similarly, in Advaita philosophy, extraneous motives cannot be attributed to brahman; instead, actions like creation are "in the very nature of brahman." ${ }^{36}$ Both God and brahman are the grounding forces of reality and existence, non-different from both, and defining reality and existence according to the necessities of their own beings.

A second similarity can be found in the relationship of humanity to God. In both traditions, humans are manifestations of the divine, non-different from their respective gods. Spinoza argues that humans, along with all things in existence, comprise modes of God's substance. The human self (as it is composed of mind and body) is one with God. Advaita philosophy promotes a similar human union with God, since atman is non-different from brahman. Thus, both systems present us with a vision of humanity as expressions of God, ultimately inseparable from the divine. The ontological non-dualism of each tradition thus extends to the human self, which is non-distinct from God or brahman.

A third and final similarity between the traditions can be found in their promotion of living liberation through knowledge of ultimate reality. In Spinozism, an intellectual love of God (intuitive, true knowledge of ultimate reality) is the highest blessedness a human can achieve. In doing so, a person is liberated from an incomplete knowledge of reality and possesses "spiritual contentment" through a recognition of the necessity of God's nature. A person who has achieved moksha in Advaita Vedanta is freed from

35 Spinoza, Ethics, 59.

36 Rambachan, Advaita Worldview, 91. 
ignorance (avidya), anxiety, and anger, and knows "peace and abiding happiness." The acknowledgement that atman is non-different from brahman is the only source of valid, necessarily true knowledge about existence. In both traditions, humans can be liberated through a realization of the ontological truth of a singularly unified ultimate reality.

Despite these striking connections between substantive facets of each tradition, some nuanced differences remain. Perhaps the principal divergence is seen in the fact that Advaita Vedanta comprises a religious tradition accepted by a community of believers throughout a significant portion of human history, while Spinozism (as presented in The Ethics) is decidedly philosophical, devoid of any explicit community of believers, and without any "religious" history.

We may observe a product of this difference in Advaita philosophy's emphasis on the importance of Hindu religious texts as conduits for human knowledge. Spinoza, conversely, proposes no equivalent textual guide for intuitive knowledge of God. Instead, humans achieve an intellectual love of God that is guided by reason. Spinoza believes that the route to blessedness and true knowledge, although ultimately intuitive, must involve reason and the intellect. Thus, rationality serves as a preliminary guide to liberation. In Advaita philosophy, this role is filled by the Upanishads, which, likewise, guide humans to an intuitive knowledge of brahman. Though the end result (knowledge of ultimate reality and human freedom) is the same, the methods for achieving such knowledge differ.

Because Advaita Vedanta philosophy is an offshoot of a major religious tradition, it is not surprising that historically-important religious texts serve as the bedrock of ontological understanding and knowledge. Similarly, it is unsurprising that Spinoza, as an Enlightenment thinker, rejects any sort of scriptural authority in favor of human intellect and reason. It cannot be doubted that this fact plays a significant role in his characterization as a Western thinker (recall that an oft-cited hallmark of the Western tradition is rational, intellectual inquiry). Although this disparity between the traditions does exist, the actual substantive claims proposed by each remain strikingly comparable: that an understanding of reality is ultimately intuitive, and that it, alone, is the source of valid knowledge.

Another apparent difference is an ontological one. Nirguna brahman, the true being of brahman, must be ineffable and without attributes. Spinoza's God, on the other hand, is described as having infinite attributes, including Thought and Extension. Are these incompatible understandings of the divine, if one god is without attributes, and the other is with infinite attributes? I would argue, in fact, that these differing characterizations of god still provide the same substantive claim-that God and brahman both transcend human understanding, and both cannot be defined or constrained. 
The Advaita adherent's concern with attributing characteristics to nirguna brahman stems from the belief that any linguistic claim placed upon brahman would serve to limit its unlimited nature. Brahman is ultimately inexpressible, because any attempt at expressing brahman is inadequate. Spinoza's God is, actually, quite similar to brahman in this way. Spinoza does believe that God must have the attributes of Thought and Extension, because these are definable human attributes, and because God (as an infinite being) must encompass all attributes. Yet, humans only have access to these two attributes: just as nirguna brahman encompasses and transcends both atman and the corporeal world, God encompasses and transcends the world and the human self as understood through Thought or Extension. Although we can speak of God as having these attributes (just as we can attribute certain characteristics to saguna brahman [brahman with attributes]), the totality of Spinoza's God remains, because of this transcendence, similarly ineffable to the totality of nirguna brahman.

Nonetheless, if the situation is as described, then we have a Western rationalist philosopher espousing an Eastern religio-philosophical doctrine. It is here that we must examine the broader implications of this comparative analysis.

In the postcolonial era, the East-West dichotomy has come under increasing attack from a variety of scholastic circles. Edward Said, an outspoken critic of such an "Orient-Occident" binary, has argued that the division is entirely mythical: that the imagined region of the Orient is, in fact, "an idea that has a history and a tradition of thought, imagery and vocabulary that has given it reality and presence for the West." 37 Said argues that, in its purported difference from the West, the very notion of the East (as espoused and understood by Westerners) is imbued with "doctrines of European superiority, various kinds of racism, imperialism and the like", and necessarily creates a power-dynamic that produces and justifies Western domination. ${ }^{38}$ Obviously, the dichotomy has proven itself tremendously controversial in recent years.

It is my hope that this comparison between Advaita Vedanta Hinduism and The Ethics might spur further critique of that problematic ideology. Through an examination of substantive similarities between Eastern and Western philosophical schools, a rigid East-West dichotomy might be unmasked as hopelessly reductionist. The argument that Spiozism so closely mirrors the ontological and epistemological claims of Advaita Vedanta Hinduism complicates the image of any fundamental ideological differences between Eastern and Western philosophy. The potential for a reexamination, and a critique of, that binary system is an intended consequence of my project.

Additionally, it is my firm belief that the type of comparative analysis exemplified in this paper provides us with a deeper understanding of seemingly disparate entities: an understanding that might have otherwise been unattainable, or entirely ignored.

37 Said, Edward W. Orientalism. (London: Routledge \& Kegan Paul, 1978), 5

38 Said, Orientalism, 8. 
When we discuss Eastern and Western philosophies in a comparative lens, fascinating results ensue. When we separate them based upon a purported incommensurability, we lose the potential for broader understandings of humanity at large, with its varied traditions and beliefs, regardless of geographic zone. I hope that further scholarly examinations of the subject matter of Spinozistic-Advaita comparative analysis might follow, so that we might see commonalities in both systems, across any imagined delineations.

\section{BIBLIOGRAPHY}

Brannigan, Michael C. The Pulse Of Wisdom: The Philosophies of India, China, and Japan. Stamford, CT: Wadsworth/Thomson Learning, 2000.

Hartshorne, Charles and William L. Reese. Philosophers Speak of God. Amherst, NY: Humanity Books, 2000.

Hongladarom, Soraj. "Spinoza \& Buddhism on the Self." The Oxford Philosopher, July 29, 2015. No page numbers.

Melamed, S.M. Spinoza and Buddha: Visions of a Dead God. Chicago: University of Chicago Press, 1933.

S. Radhakrishnan, trans., The Principal Upanishads. London: Allen \& Unwin, Ltd., 1953.

Rambachan, Anantanand. The Advaita Worldview: God, World, and Humanity Albany, NY: State University of New York Press, 2006.

Russell, Bertrand. A History of Western Philosophy. London: Allen \& Unwin, 1946.

Said, Edward W. Orientalism. London: Routledge \& Kegan Paul, 1978.

Spinoza, Baruch. The Ethics, Treatise on The Emendation of the Intellect, and Selected Letters. Translated by Samuel Shirley. Edited by Seymour Feldman. 2nd ed. Cambridge: Hackett Pub. Co., 1992.

Ziporyn, B. (2012). Spinoza and the Self-Overcoming of Solipsism. Comparative and Continental Philosophy, 4(1), 125. 